\title{
Remediation of Abandoned Saline Soils Using Glycyrrhiza glabra: A Study from the Hungry Steppes of Central Asia
}

\author{
Habibjon Kushiev ${ }^{1}$, Andrew D. Noble ${ }^{2}$, Iskandar Abdullaev ${ }^{3}$ and Uktam Toshbekov ${ }^{4}$ \\ ${ }^{1}$ General Biology Department, Gulistan State University, Gulistan, Uzbekistan; ${ }^{2}$ International Water Management \\ Institute, Southeast Asia Regional Office, WorldFish Centre, PO Box 500, GPO 10670, Penang, Malaysia; ${ }^{3}$ International \\ Water Management Institute, Central Asia Office, Tashkent 7000000, Uzbekistan; and ${ }^{4}$ Basics of Agriculture Department, \\ Gulistan State University, Gulistan, Uzbekistan
}

\begin{abstract}
Large expansion of the irrigated area in the Aral Sea Basin has exacted a substantial toll on land and water resources in the region. Elevated water tables associated with poor irrigation management and inappropriate drainage infrastructure have resulted in significant secondary salinisation of crop lands resulting in declining cotton and wheat yields and eventual abandonment of lands. Costs associated with the installation of appropriate drainage infrastructure in order to reclaim these areas are prohibitive and hence alternative approaches are required that can be adopted by resource poor farmers. In the current study the potential use of Glycyrrhiza glabra (common name liquorice) to reclaim abandoned saline areas was assessed over a four year period before being returned to a cotton/wheat crop rotation. Two adjacent abandoned fields of 10 and 13 ha respectively were selected for the study on which two treatments were imposed, namely, a control that was maintained as a bare fallow between 1999 and 2003 and a treated plot where liquorice was established over this period. High quality livestock forage with a protein content of $12 \%$ was cut from the liquorice plot with dry matter yields ranging from $3.66( \pm 0.06)$ to $5.11( \pm 0.17) \mathrm{t} \mathrm{ha}^{-1}$. In addition, root dry matter yields of $5.63( \pm 1.19)$ to $8.55( \pm 0.82) \mathrm{t} \mathrm{ha}^{-1}$ were recorded, this plant component being used in the preparation of herbal medicines and soft drinks. At the end of four years both plots were returned to a wheat and cotton crop rotation. Yields of wheat on the control and treated plots were $0.87( \pm 0.05)$ and $2.42( \pm 0.02) \mathrm{t} \mathrm{ha}^{-1}$ respectively. Similarly substantial increases in cotton were observed with the control and treated plots yielding $0.31( \pm 0.01)$ and $1.89( \pm 0.18) \mathrm{tha}^{-1}$. These levels of production on the treated plot exceed the district average for wheat and cotton of 1.75 and $1.5 \mathrm{tha}^{-1}$ respectively, clearly showing the positive benefit associated with the growing of liquorice. Water table levels after four years were maintained below the critical level of $2.5 \mathrm{~m}$ in the treated plots whilst rising to within $1.99 \mathrm{~m}$ from the surface in the control. Salt content of the soil in the treated plot declined over the study while those in
\end{abstract}

the control increased. This preliminary study has clearly demonstrated the ameliorating affect of liquorice in bringing abandoned salt affected soils back into production that is low cost and could be adopted by resource poor farmers.

Keywords: saline soils, bioremediation, Glycyrrhiza glabra, wheat, cotton

\section{Introduction}

The Aral Sea basin is dominated by two main rivers, the Amu Darya and Syr Darya that discharge into the Aral Sea. The potential annual inflow of these two rivers into the sea amounts to $109 \mathrm{~km}^{3}$, however in recent years the inflow has declined to a mere trickle because of largescale irrigation withdrawals (Cai et al., 2003). In the 1960s the Aral Sea was the world's fourth largest inland lake; by the early 1990s the sea had shrunk to approximately half its size and was three times more saline (Micklin, 1991). This has had a major impact on the livelihoods of 4-5 million people who depend directly on the Aral Sea for goods and services. Moreover the development of unsustainable irrigation schemes in the region has had extensive environmental and ecological impacts associated with elevated water tables; the abandonment of large tracks of land due to salinisation; declining crop productivity and returns on investments; and enhanced salinity levels in irrigation return flows to the two dominant rivers that has had a profound effect on aquatic species and quality of water.

The dominant approach adopted by irrigation farmers to mitigate salinity in the region is to 
apply excessive amounts of water to salt-affected fields in order to leach salts below the effective root zone. It has been estimated that between $20-25 \%$ of the annual available surface water in the region is used for leaching which could otherwise be delivered to the Aral Sea as increased environmental flow and also represents extremely low levels of water productivity (WEMP, 2003). In addition, the application of excess surface water to fields has resulted in the development of elevated water tables that effectively exacerbates the problem through the mobilisation of further salt. When soils become highly saline farmers tend to abandon affected fields resulting in large tracks of saline/ waterlogged soils.

It is estimated that annually between $2-3 \%$ of the irrigated area of the Hungry Steppe (Mirzachul) - one of the largest irrigated regions of Central Asia - is taken out of crop production due to salinisation. The rehabilitation of these salinised areas requires major technical expertise and financial investment. A recent assessment of the costs associated with the rehabilitation of the salinised soils in the Hungry Steppes was in excess of USD\$ 2 billion (World Bank, 2003). Whilst these costs include the development of substantial irrigation and drainage infrastructure in the reclamation process, there are potential cost effective strategies that can be used in the rehabilitation process that involves plant-based production systems.

The use of plants in the remediation of saline and sodic soils is an emerging low cost approach in the reclamation of abandoned irrigated fields (Kumar \& Abrol, 1984; Muhammed et al., 1990; Pankova et al., 1994, 1996; Qadir et al., 2002, 2005; Tokhtarov, 2004). In this respect, the creation of highly productive fodder systems through the establishment of palatable halophytes has been shown to remediate saline/ sodic soils as well as provide an income to resource poor farmers (Dagar et al., 2004; Helalia et al., 1992; Hyder, 1981). Halophytes are ecologically and physiologically specialised plants that are capable of producing high yields under saline conditions. The ability of the halophytes to function under saline environments is dependent on their specific ecological, physiological and biochemical attributes (Akjigitova, 1981; Hinsinger, 1998). The introduction of the halophyte Glycyrrhiza glabra (commonly referred to as liquorice) in the reclamation of saline soils and the subsequent restoration of irrigated cropping systems has been demonstrated in several studies (Badalov et al., 1996; Kerbabaev, 1971; Mihailova, 1966; Pauzner, 1971). However, the quantification of the impact of reclamation on subsequent crops has not been the focus of these previous studies.

Liquorice belongs to the leguminous family (Fabaceae L.) and is one of 13 species in this family. It is a perennial shrub species that grows to a height of $1.5 \mathrm{~m}$. The plant has a fusiform root system with numerous suckers that are often more than $1 \mathrm{~m}$ in length. However, in many cases roots of an individual plant often reach $17 \mathrm{~m}$ in arid areas in order to access deep ground water. Liquorice is a shrub native to southern Europe and Asia, the roots of which have two primary desirable qualities. Firstly, some varieties of liquorice root are 50 times sweeter than sugar and may be chewed or eaten as a sweet making it a useful component of sweets and flavourings. Secondly, liquorice has been sought after for thousands of years for its reputed medicinal qualities. Glycyrrhizic acid is extracted from the root and used as a flavouring in food, tobacco, alcohol and cosmetics. The plant is commonly grown in Asia for its root as it is used for medicinal purposes and a fodder source for livestock. Five species of liquorice have been found to be well adapted to the climatic and edaphic conditions of the Hungry Steppes and have been shown to produce large amounts of forage along with root material that can be processed for medicinal purposes.

The current study was undertaken to assess the efficacy of Glycyrrhiza glabra in rehabilitating an abandoned salt affected field on the Hungry Steppes of Uzbekistan on the productivity of subsequent crops. The field study was conducted over four years and in the final year established a cotton-wheat rotation. Changes in soil chemical properties, water table height and yield responses in cotton and wheat post-rehabilitation are presented.

\section{Methods and Materials}

\section{Site description}

A field experiment was established at a site of Gulistan State University, located on the shirkat (collective farm) 'Navbahor', Bayauut district of Syr Darya province, Uzbekistan, in the Mirzachul valley, Hungry Steppes $\left(40^{\circ} 8^{\prime} \mathrm{N}\right.$ 
and $\left.69^{\circ} 52^{\prime} \mathrm{E}\right)$. The region is characterised as having a sharp continental climate, with hot and long summers and cold and wet winters. Mean annual rainfall for the region is $300 \mathrm{~mm}$ that falls almost entirely as snow during the winter months. The temperatures fluctuate throughout the year with summer temperatures reaching $46^{\circ} \mathrm{C}$ and winter temperatures dropping to below $-46^{\circ} \mathrm{C}$. Soil surface temperatures during the summer often exceed $50^{\circ} \mathrm{C}$.

Two adjacent fields of 10 and 13 ha respectively were selected for the study. These fields were on land that had been abandoned due to the presence of high salinity. The check or control field was established on the 10 ha field whilst liquorice (treated) was established on the 13 ha field. The fields fall within a slight topographic depression with no natural or artificial drainage, and the soils have within them salt-bearing parent material. As a consequence of inappropriate irrigation practices the fields have become salinised due to the presence of an elevated water table that often approaches the top $1 \mathrm{~m}$ and results in the mobilisation of salt that is within the profile. The soil is classified as a light textured serozem (Rozanov, 1989). These fields are typical of abandoned salinised farmer fields throughout the Hungry Steppes.

\section{Pilot demonstration plots and agronomy}

The control treatment was left in its abandoned state throughout the duration of the study with only routine soil sampling and water table monitoring being undertaken. In contrast, all 13 ha of the treated plot was established with liquorice in October 1999 and kept under the same crop until 2003. At the end of the summer growing season in 2003, two 1 ha plots in the control and treated fields were prepared for the establishment of winter wheat and cotton in the same growing season (Figure 1).

At the start of the study in 1999 both sites were levelled and ripped using a chisel plough to a depth of $25 \mathrm{~cm}$. In the autumn of 1999 (October), 50,000 rhizomes of liquorice of between 2-5 cm in length were planted in the treated plot, whilst the control was retained as a bare fallow. The crop was allowed to develop over 2000 and harvesting of above ground biomass for animal feed was undertaken in 2001, 2002 and 2003. Yield assessment of above ground biomass was undertaken on three $100 \mathrm{~m}^{2}$ plots within the trial site. In the first

\begin{tabular}{|c|c|c|c|c|c|c|}
\hline Treatment & \multicolumn{6}{|c|}{ Year } \\
\hline & 1999 & 2000 & 2001 & 2002 & 2003 & 2004 \\
\hline \multicolumn{7}{|l|}{ Control } \\
\hline Treated & & & & & & \\
\hline Liquorice & & 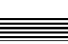 & & & & \\
\hline Bare fallow & & & & & & \\
\hline
\end{tabular}

Figure 1 Cropping calendar for the control and treated plots for the period 1999 to 2004. Liquorice (Glycyrrhiza glabra) was established in October 1999

year of establishment, liquorice received four irrigations applied at rates of $80-100 \mathrm{~mm}$. The number of irrigation events in 2001, 2002 and 2003 declined to 3, 2 and 2 respectively over this period. In the control treatment, leaching of salts from the profile were routinely undertaken in the winter months from 2000 to 2003 with an application of $350 \mathrm{~mm}$. This is a standard practice undertaken by farmers in the region to get rid of soluble salts that accumulate in the profile over the summer growing season. Fertilisers were applied twice annually to the liquorice plot, at the beginning of the growing season (spring) and in the fall after harvest of the above ground biomass. Rates of application were as follows: $150 \mathrm{~kg} \mathrm{~N}, 56 \mathrm{~kg} \mathrm{P}$ and $50 \mathrm{~kg} \mathrm{~K} \mathrm{ha}{ }^{-1}$.

At the end of the summer growing season in 2002 and 2003 liquorice was removed from the two 1 ha plots and the yield of roots determined. The mass of roots was determined in three $5 \mathrm{~m}^{2}$ quadrats and a sub-sample collected for moisture determination by oven drying at $65^{\circ} \mathrm{C}$. In 2003 the cleared area was then prepared for the establishment of winter wheat. Similarly, a 1 ha plot was prepared in the adjacent control plot. Wheat was sown at a rate of $210 \mathrm{~kg} \mathrm{ha}^{-1}$ within each of the treated and control plots, three $1 \mathrm{~m}^{2}$ plots were demarcated and 500 seeds were broadcast evenly over the area. These plots were used to assess germination percentage and tillering. Dates of floral initiation and physiological maturity were recorded during the growing season. At harvest three random $5 \mathrm{~m}^{2}$ quadrats were demarcated in each of the treatments and the number of wheat heads, weight of heads and yield were recorded. Sub-samples were collected from each quadrat for moisture determination. Yields were adjusted to a $14 \%$ moisture content.

On the second 1 ha plot in each of the treatments, cotton was sown on the 23rd April 2004. In each of the plots three $1 \mathrm{~m}^{2}$ quadrats were demarcated and 
100 seeds sown and germination assessed on 7th May 2004. At harvest the number of bolls per plant and an assessment of cotton yield were undertaken on three $5 \mathrm{~m}^{2}$ quadrats.

\section{Water table and soil salinity monitoring}

The site on which the study was established was classed as highly saline due to the presence of an elevated water table. In order to assess the impact of treatments on water table levels, three piezometers were installed to a depth of $7 \mathrm{~m}$ in each of the treatment plots. The height of the water table was assessed on a monthly basis for the duration of the study and water samples were collected for the determination of total dissolved salts (TDS).

Soil samples were collected annually from 2000 through to 2003 prior to land preparation activities for the establishment of the wheat/cotton crops. Samples were collected from three random points within the treated plots over a $2 \mathrm{~m}$ depth at $25 \mathrm{~cm}$ intervals from a $0-100 \mathrm{~cm}$ depth and at $50 \mathrm{~cm}$ depth intervals from 100-200 cm depths. A single composite sample for each depth interval was prepared for each treatment. The samples were analysed according to Souyznikhi (Cotton Growing Scientific Research Institute, 1973) in which the $\mathrm{Ca}^{2+}$, $\mathrm{Mg}^{2+}, \mathrm{Na}^{+}, \mathrm{SO}_{4}^{2-}, \mathrm{Cl}^{-}$and $\mathrm{HCO}_{3}^{-}$were determined on extracts to assess the degree of salinity. In order to assess the degree of remediation associated with the treatments, profile salt content was calculated on an annual basis for the profile (i.e. $0-2 \mathrm{~m}$ ). Soil organic matter was determined on three randomly collected samples from the $0-50$ and $50-100 \mathrm{~cm}$ depth intervals on an annual basis using the methodology of Turin (Cotton Growing Scientific Research Institute, 1973).

\section{Results}

\section{Liquorice yields}

The yields of above ground biomass for the period 2001 to 2003 are presented in Figure 2. After the establishment of the pasture in October 1999, harvesting of the above ground biomass was not undertaken until the growing season of 2001 when yields of $3.66( \pm 0.06) t^{~ h a} a^{-1}$ were recorded. Over the intervening two years, 2002 and 2003, forage yields from the plot progressively increased and reached a maximum of $5.11( \pm 0.17) \mathrm{t} \mathrm{ha}^{-1}$ (Figure 2). The protein content of the above ground biomass was determined to be $12 \%$. It is interesting to note that over this period the frequency of irrigations declined from four events to two, suggesting that as the crop established and developed a deeper root system, it was able to access stored subsurface moisture. In 2002 and 2003 treated

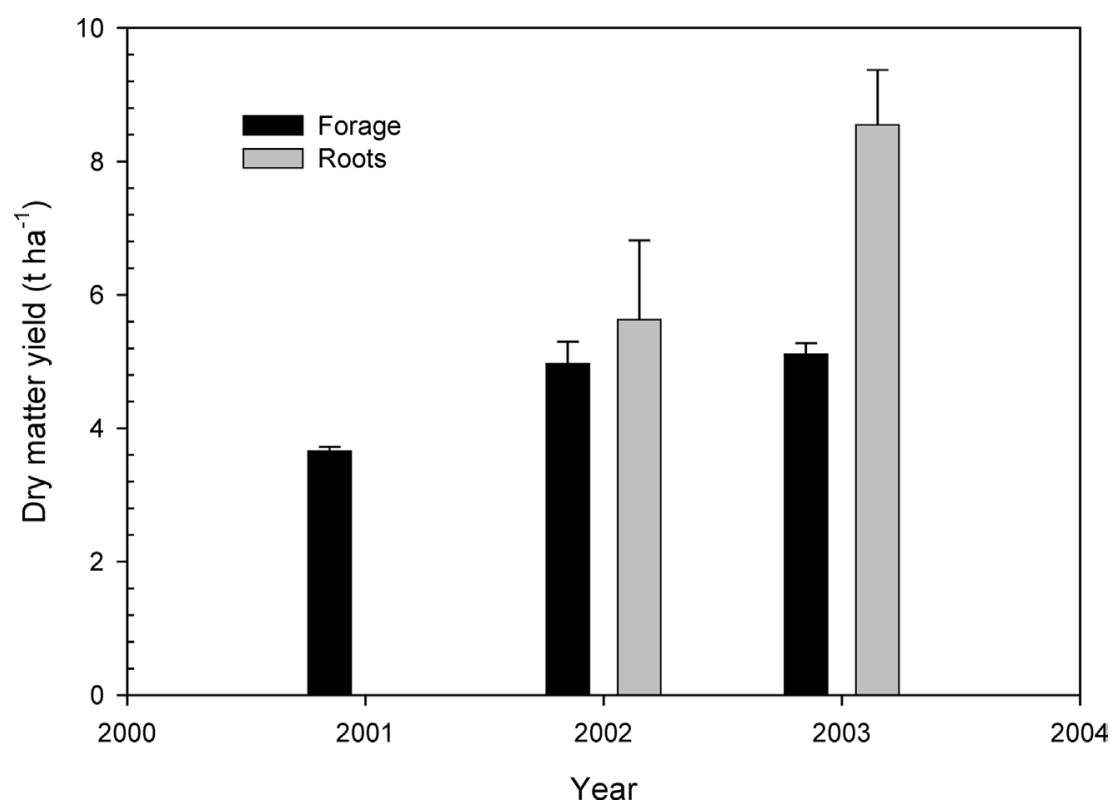

Figure 2 Dry matter yields of forage and roots from plots established to liquorice over the period 2001 to 2003 . The crop was established in October 1999. Vertical bars are the standard error of the mean for three replicates 
plots were harvested for the roots of liquorice. Yields ranged from $5.63( \pm 1.19)$ to 8.55 $( \pm 0.82) \mathrm{tha}^{-1}$ in 2002 and 2003 respectively (Figure 2). The raw roots are used in the preparation of beverages and medicinal preparations.

\section{Wheat and cotton agronomic attributes}

Selected agronomic attributes were assessed throughout the growing season for each of the crops and the yields of wheat and cotton are presented in Table 1 for the year 2004. The germination of both wheat and cotton seeds was severely inhibited on the control plot with only $30 \%$ and $15 \%$ of the wheat and cotton seeds germinating on the plot. In contrast, $71 \%$ and $67 \%$ of the wheat and cotton seeds were able to germinate and survive on the treatment plot that had previously been established with liquorice. This had a major impact on stand density and ultimately yields of wheat and cotton. Floral initiation and physiological maturity of the wheat crop occurred earlier in the case of the control treatment. The components that contribute to overall yield, namely number of tillers, heads and head weight, were all significantly higher in the treatment having previously been under liquorice (Table 1). The final yield of wheat grain at $14 \%$ moisture varied from 0.87 to $2.42 \mathrm{tha}^{-1}$ on the control and treated plots respectively, clearly indicating the benefits derived from the previous crop of liquorice (Table 1).

Similarly, productivity gains were observed with respect to cotton production on plots previously established with liquorice (Table 1). The number of bolls per plant was significantly higher in the treatment plot when compared to the control and this resulted in a six-fold increase in yield from 0.31 to $1.89 \mathrm{t} \mathrm{ha}^{-1}$ cotton (Table 1). The average yields of wheat and cotton for the Hungry Steppes is 1.75 and $1.5 \mathrm{t} \mathrm{ha}^{-1}$ respectively. The yields obtained for each of these crops on the liquorice treatment exceeded these regional average yields and clearly demonstrated the ameliorative potential of this approach.

\section{Water table height}

Through over irrigation and inadequate infield drainage elevated water tables will develop. The development of an elevated water table results in the mobilisation of profile salt and its subsequent deposition on the surface and in sub-surface horizons through capillary rise, is the dominant cause of in field salinity. The piezometer height of the water table was routinely assessed on a monthly basis from 2000 to 2003. Briefly, the mean monthly height for the control and treated plots are presented in

Table 1 The effects of contrasting management options to remediate abandoned highly saline soils on the control and treated (liquorice) on the productivity of wheat and cotton crops established four years after the initial establishment of liquorice. Values in parenthesis are the standard error of the mean of three replicates

\begin{tabular}{|c|c|c|}
\hline Measured parameter & Control & Liquorice \\
\hline & \multicolumn{2}{|c|}{ Wheat } \\
\hline Percent germination $(\%)$ & $30.0( \pm 1.5)$ & $71.3( \pm 2.4)$ \\
\hline Number of tillers per plant & $1.46( \pm 0.21)$ & $2.60( \pm 0.25)$ \\
\hline No of wheat heads $\left(\mathrm{m}^{-2}\right)$ & $106.7( \pm 4.9)$ & $237.7( \pm 16.1)$ \\
\hline Weight of wheat head $\left(\mathrm{g} \mathrm{head}^{-1}\right)$ & $0.77( \pm 0.02)$ & $1.20( \pm 0.10)$ \\
\hline $\begin{array}{l}\text { Yield of wheat grain at } 14 \% \\
\text { moisture }\left(\mathrm{t} \mathrm{ha}^{-1}\right)\end{array}$ & $0.87( \pm 0.05)$ & $2.42( \pm 0.02)$ \\
\hline Floral initiation period & 15th April-3rd May 2004 & 29th April-10th May 2004 \\
\hline \multirow[t]{2}{*}{ Physiological maturity } & 29th May 2004 & 13th June 2004 \\
\hline & \multicolumn{2}{|c|}{ Cotton } \\
\hline Percent germination $(\%)$ & $15.0( \pm 2.0)$ & $67( \pm 1.5)$ \\
\hline Bolls per plant at harvest & $4.0( \pm 0.5)$ & $6.4( \pm 0.6)$ \\
\hline Yield of cotton $\left(\mathrm{t} \mathrm{ha}^{-1}\right)$ & $0.31( \pm 0.01)$ & $1.89( \pm 0.18)$ \\
\hline
\end{tabular}


Figure 3. It is clearly evident from Figure 3 that there are seasonal fluctuations in the depth to water table, with levels being closer to the surface during the winter months (January-April) and decreasing during the summer growing season reaching a maximum depth in September, the end of the growing season (Figure 3). The water table depth of treatments in September for each year between 2000 and 2003 clearly shows the water table moving closer to the surface in the control treatment when compared to the liquorice plot (Figure 4). In September 2003 the difference between treatments reached a maximum of $80 \mathrm{~cm}$ (Figure 4). During the period 2000 to 2003 the mean water table depth over all months decreased under the control plot from a mean of $252 \pm 6$ to $199 \pm 2 \mathrm{~cm}$ from the surface (Figure 4).
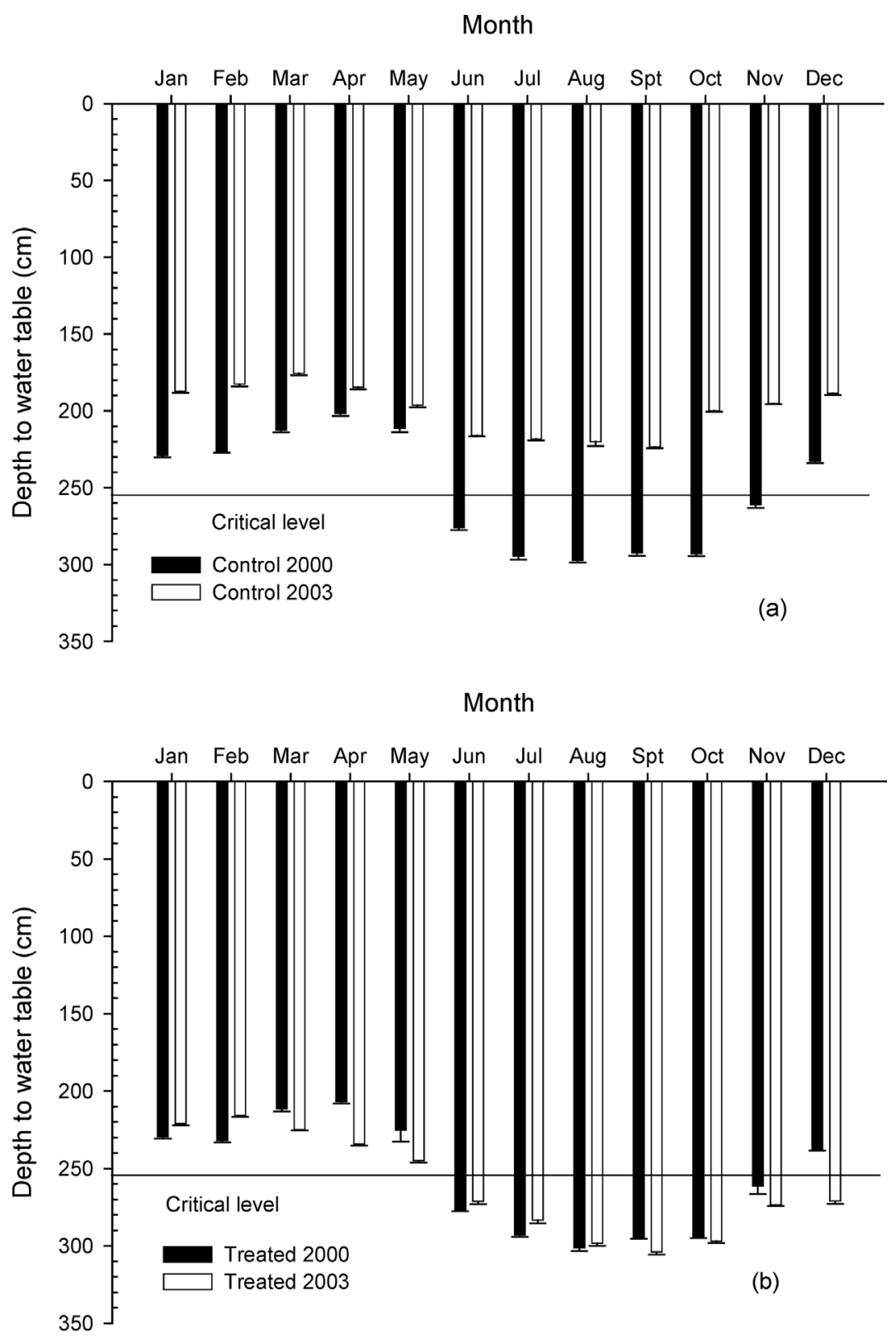

Figure 3 Changes in the water table height in the control (a) and treated (b) plots over the period 2000 to 2003. Vertical bars are the standard error of the mean of three replications and the horizontal line represents the critical level depth to surface required for the production of cotton and wheat 


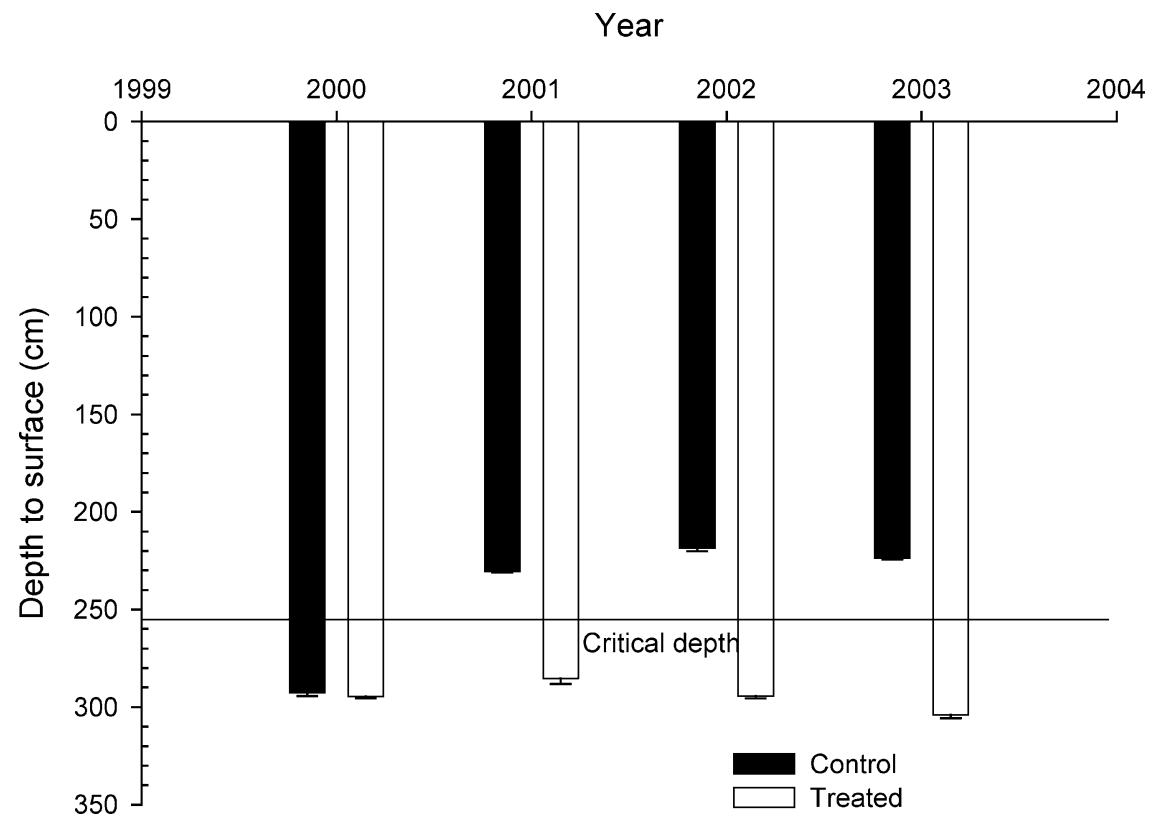

Figure 4 Changes in the mean depth of water table from the surface measured in the water table height in September of each year between 2000 and 2003 for the control and treated plots. Vertical bars are the SE of the mean for three replications and the horizontal line represents the critical depth for the production of cotton and wheat

Contrasting this, the water table depth under the treated plot increased from $243 \pm 4$ to $262 \pm 5 \mathrm{~cm}$ from 2000 to 2003. As both fields had inadequate in-field drainage infrastructure, the effect of liquorice in maintaining if not decreasing the level of the water table, is clearly evident.

The impact of establishing liquorice on the quality of ground water was assessed by determining the concentration of total dissolved salts (TDS) on composite samples collected from piezometers on a monthly basis. The TDS of the ground water in the control plot increased from 5.19 to $6.11 \mathrm{~g} \mathrm{l}^{-1}$ over the period 2000 to 2003 , indicating that there had been mobilisation of salts from the profile associated with the rising water table. Under the liquorice treatment the TDS declined over the same period from 6.35 to $3.99 \mathrm{~g} \mathrm{l}^{-1}$, indicating that salts had been lost from the system. This may in part be attributed to uptake by the crop and/ or re-precipitation within the profile. According to Rahimabaev and Gasnova (1980), the critical depth and TDS of the ground water for the Hungry Steppes that would effectively diminish the risk of salinisation of surface horizons are $2.5 \mathrm{~m}$ and $4.5 \mathrm{~g}^{-1}$. In the case of the liquorice treatment both of these critical levels were achieved prior to the establishment of the wheat and cotton crops.

\section{Soil chemical changes}

The composition of soil extracts assessed over a $2 \mathrm{~m}$ depth interval for 2000 and 2003 is presented for selected cations and anions in Table 2. The dominant cations and anions contributing to salinity in these soils are $\mathrm{Mg}^{2+}, \mathrm{Ca}^{2+}$ and $\mathrm{SO}_{4}^{2-}$ that are commonly observed as $\mathrm{MgSO}_{4}$ and $\mathrm{CaSO}_{4}$ crystals within the soil profile. At the beginning of the study in 2000, the levels of salt within both of the treatment plots were similar, although the control treatment had higher $\mathrm{Na}^{+}$concentrations throughout the profile when compared to treated plot resulting in a higher sodium absorption ratio (SAR) for all depth intervals (Table 2). Contrasting this, the treated plot had elevated $\mathrm{Ca}^{2+}$ and $\mathrm{Mg}^{2+}$ concentrations in the top $50 \mathrm{~cm}$ when compared to control (Table 2). After four years under liquorice, extractable cations and anions declined markedly in this treatment when compared to the original concentrations that were measured in 2000 (Table 2). This was not the case in the control treatment where there was an upward movement of salts (i.e. $\mathrm{Ca}^{2+}$ and $\mathrm{Mg}^{2+}$ ).

An assessment of the salt content within the profile over the four year period prior to the establishment of wheat and cotton is presented in Figure 5. The initial total salt content in the 
Table 2 Selected changes in extractable cations and anions ( $\mathrm{mol} \mathrm{l}^{-1}$ ) over the period 2000 to 2003 associated with the control and treated plots

\begin{tabular}{|c|c|c|c|c|c|c|c|c|c|c|c|c|}
\hline \multirow{2}{*}{$\begin{array}{l}\text { Depth } \\
\text { (cm) }\end{array}$} & \multicolumn{2}{|c|}{$\mathrm{Ca}^{2+}$} & \multicolumn{2}{|c|}{$\mathrm{Mg}^{2+}$} & \multicolumn{2}{|c|}{$\mathrm{Na}^{+}$} & \multicolumn{2}{|c|}{$\mathrm{Cl}^{-}$} & \multicolumn{2}{|c|}{$\mathrm{SO}_{4}^{2-}$} & \multicolumn{2}{|c|}{ SAR } \\
\hline & 2000 & 2003 & 2000 & 2003 & 2000 & 2003 & 2000 & 2003 & 2000 & 2003 & 2000 & 2003 \\
\hline \multicolumn{13}{|c|}{ Control } \\
\hline $0-25$ & 1.470 & 2.416 & 1.516 & 2.316 & 1.937 & 1.882 & 0.565 & 0.862 & 4.016 & 5.454 & 1.12 & 0.86 \\
\hline $25-50$ & 1.485 & 2.127 & 1.465 & 2.416 & 1.978 & 1.981 & 0.518 & 0.824 & 4.105 & 5.348 & 1.15 & 0.93 \\
\hline $50-75$ & 1.765 & 1.765 & 1.642 & 2.054 & 2.264 & 2.207 & 0.508 & 0.759 & 4.865 & 4.962 & 1.22 & 1.12 \\
\hline $75-100$ & 1.825 & 2.542 & 2.018 & 2.625 & 2.074 & 1.944 & 0.501 & 0.658 & 5.116 & 5.105 & 1.05 & 0.86 \\
\hline $100-150$ & 1.860 & 1.854 & 2.110 & 2.154 & 1.951 & 1.722 & 0.487 & 0.592 & 5.080 & 4.856 & 0.98 & 0.86 \\
\hline $150-200$ & 2.018 & 1.875 & 2.220 & 2.064 & 1.943 & 1.856 & 0.469 & 0.573 & 5.378 & 4.978 & 0.94 & 0.93 \\
\hline \multicolumn{13}{|c|}{ Treated } \\
\hline $0-25$ & 1.530 & 1.010 & 2.412 & 1.105 & 0.434 & 0.368 & 0.574 & 0.114 & 3.448 & 2.135 & 0.21 & 0.25 \\
\hline $25-50$ & 1.554 & 1.050 & 2.465 & 1.235 & 0.350 & 0.261 & 0.552 & 0.094 & 3.492 & 2.224 & 0.17 & 0.17 \\
\hline $50-75$ & 1.785 & 1.060 & 1.924 & 1.240 & 1.147 & 0.236 & 0.548 & 0.148 & 4.000 & 2.284 & 0.59 & 0.15 \\
\hline $75-100$ & 1.812 & 1.344 & 2.325 & 1.180 & 0.727 & 0.854 & 0.514 & 0.198 & 4.022 & 3.086 & 0.36 & 0.53 \\
\hline $100-150$ & 1.860 & 2.134 & 2.342 & 1.338 & 0.653 & 0.748 & 0.486 & 0.264 & 4.024 & 3.848 & 0.32 & 0.40 \\
\hline $150-200$ & 2.020 & 2.647 & 2.354 & 2.384 & 0.921 & 0.866 & 0.461 & 0.490 & 4.534 & 5.297 & 0.44 & 0.38 \\
\hline
\end{tabular}

top $2 \mathrm{~m}$ depth of soil in 2000 in the liquorice plot was estimated to be $215 \mathrm{t} \mathrm{ha}^{-1}$ (Figure 5). By 2003 the total salt content had declined to $185 \mathrm{t} \mathrm{ha}^{-1}$ or a $14 \%$ decline in total salt. In contrast, on the control plot that underwent a routine leaching phase in the winter where $350 \mathrm{~mm}$ was applied, the total salt content increased by $31 \%$ from $210 \mathrm{tha}^{-1}$ to $305 \mathrm{tha}^{-1}$ between 2000 and 2003
(Figure 5). These results clearly indicate the ameliorative effect of establishing liquorice on the total salt balance for the plot, but more importantly, the ineffectiveness of the commonly prescribed annual leaching programme that farmers routinely undertake in the absence of a functional drainage system. Moreover, it would appear that in the latter case the situation has

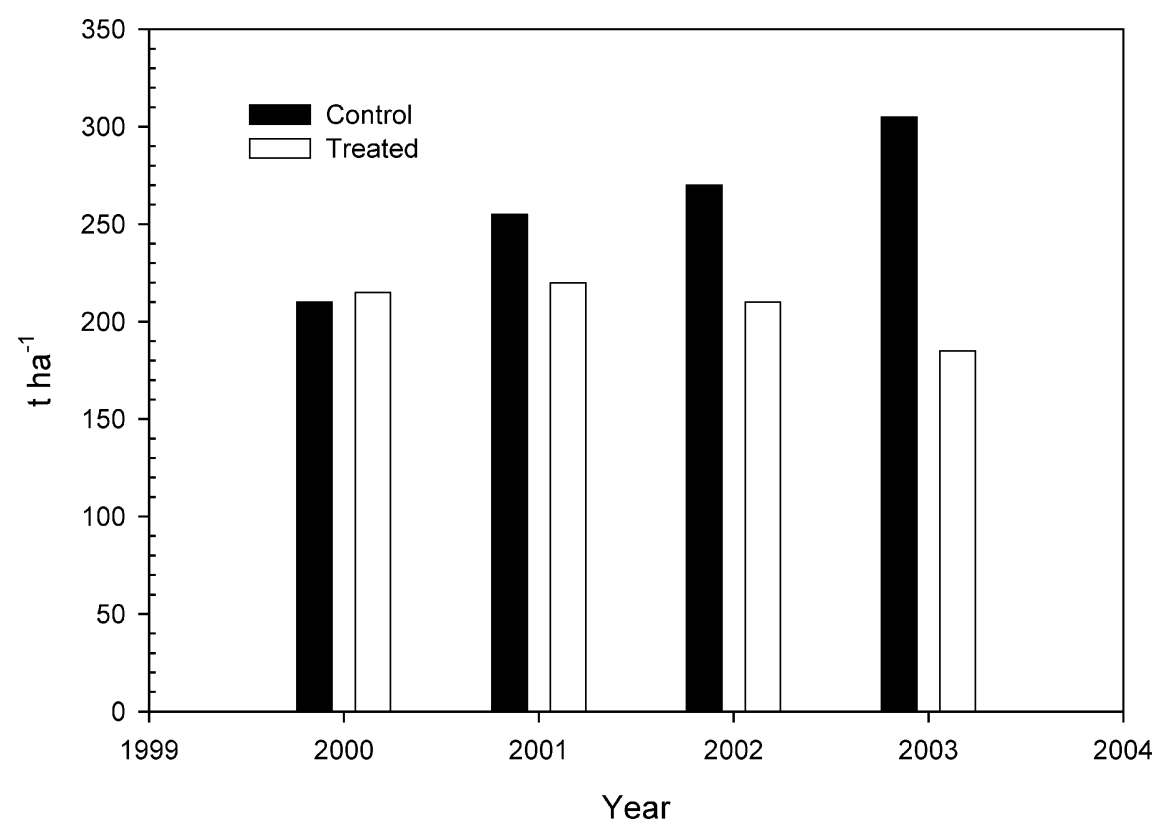

Figure 5 Estimated salt content for the $2 \mathrm{~m}$ depth interval on an annual basis for the control and treated plots 
been exacerbated with greater levels of salt accumulation in the profile.

Soil organic matter levels were measured routinely during the period under licoirce for both the control and treated plots (Figure 6). Composite samples for the $0-50$ and $50-100 \mathrm{~cm}$ were collected and the organic matter content determined. Organic matter contents remained unchanged for both the sampling depths in the control treatment over the intervening four year period from 2000 to 2003 which is to be expected as the plot remained devoid of any vegetation. In contrast the liquorice plot showed substantial increases in organic matter over both sampling depths between 2000 and 2003 (Figure 6). This is attributed to the prolific and extensive root system of the species and possibly the organic exudates associated with root growth. The positive impact of higher organic matter on soil properties, including aggregate stability and hydraulic conductivity, would significantly enhance the amelioration process. However, it is of note that organic matter additions have little or no effect on the aforementioned soil physical attributes unless microorganisms are present (Lynch \& Bragg, 1985). There are several mechanisms by which micro-organisms are involved in stabilising soil structure: first, by directly
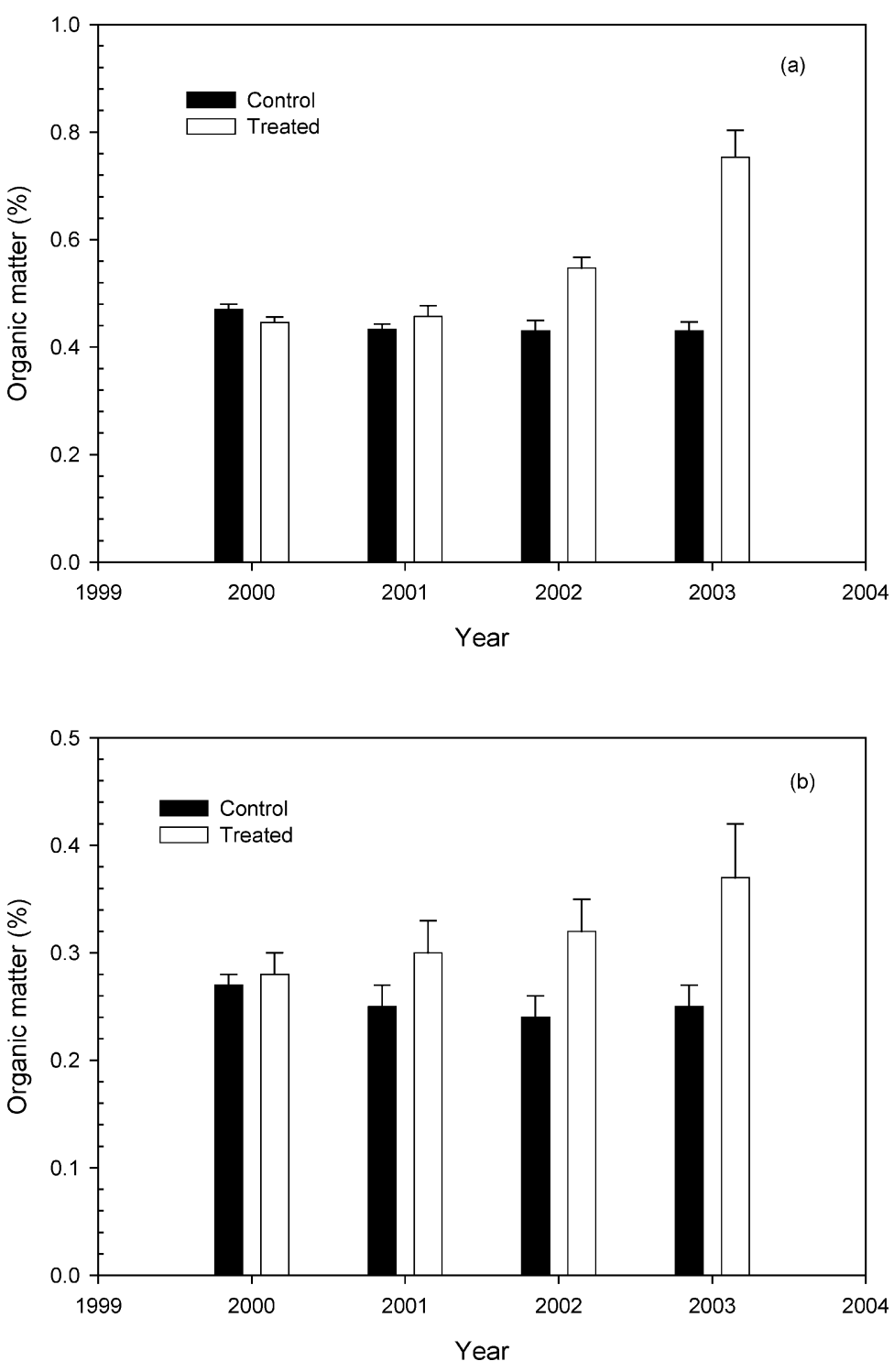

Figure 6 Percent organic matter content of the $0-50 \mathrm{~cm} \mathrm{(a)} \mathrm{and} \mathrm{50-100} \mathrm{cm} \mathrm{(b)} \mathrm{depth} \mathrm{interval} \mathrm{over} \mathrm{the} \mathrm{course} \mathrm{of}$ four years for the control and treated plots. Vertical bars represent the SE mean for three replications 
providing mechanical binding between soil particles; second, by producing cementing materials during the decomposition of organic materials; and last, micro-organisms also serve as a substrate for further microbial growth (Kay \& Angers, 2000). Whilst microbial biomass was not measured during the study, it is an area that needs to be explored with respect to the amelioration process.

\section{Discussion and Conclusions}

The problem of soil salinity and waterlogging and their remediation is a vexing issue challenging governments of the newly independent states of Central Asia region. In Uzbekistan alone, between $45-50 \%$ of water management related funding is channelled into rehabilitating degraded drainage infrastructure, and in southern Kazakhstan the government will invest between US\$200-300 million dollars over the next five years in addressing salinity. These are substantial investments for emerging economies that have limited resources and significant socio-economic issues to address. With the breakup of the former Soviet States and their independence, economies in several of these countries have contracted, with associated socio-economic, environmental and food security issues attaining greater prominence. Saline areas are generally found in poorer areas of the region with per capita incomes 30\% lower than average national indicators and unemployment levels 40\% higher (Abdullaev, 2004). Technical strategies for arresting salinity are invariably capital intensive and are often beyond the means of the national budgets of the regions governments. The approach demonstrated in the current study effectively provides an alternative strategy to addressing the issue of reclaiming abandoned saline soils through vegetative bioremediation. Results clearly demonstrate that after a four year period under liquorice, indicators of salinity, namely water table levels and soil and water salinity levels, declined significantly and allowed the site to be returned to a highly productive wheat/cotton rotation. In addition, the subsequent productivity of wheat and cotton crops was greater than the regional average, suggesting increases in income to farmers particularly where production of these commodities is controlled by the state and is based on the potential of the soil (i.e. Bonnitet value). These soils would be classified as having a low Bonnitet value and hence production potential. Any surplus production of these commodities above the controlled state quota (termed the Plan) can be sold or traded by the individual farmers in the local market place for their own benefit.

As indicated previously, the major limitation associated with the remediation of saline soils is the high capital cost. In this respect the construction of sub-surface drainage infrastructure to lower water tables and facilitate the leaching of soluble salts is estimated to cost US\$ $2000 \mathrm{ha}^{-1}$ whilst the implementation, operation and maintenance of a vertical drainage system costs approximately US\$2500 $\mathrm{ha}^{-1}$ (MAWR, 2002). The cost of establishment and maintenance of a crop of liquorice was estimated to be approximately US\$ $50 \mathrm{ha}^{-1}$. In addition, the crop has the potential to generate income for farmers over the remediation period through the production of high quality forage for feeding to livestock and the sale of root material at plough-out that can be used in drinks and medicinal preparations, resulting in a net positive income. A comprehensive assessment of the economic benefits arising from the production and sale of the roots cannot be undertaken as a formal market has yet to be established. However, a major advantage of this approach to remediation is that it can be adopted by individual farmers and does not require the collective action of a community or irrigation command area as is commonly a prerequisite for several technical approaches. It should be noted that the role of bioremediation as demonstrated in this study does not negate the role of effective and functional drainage infrastructure in the management of salinity, but more importantly, offers one alternative to remediating abandoned saline lands and an interim measure in the management of saline soils.

An annual strategy commonly advocated and undertaken by farmers in the region is to leach salt from their fields during the winter. Applications in excess of $350 \mathrm{~mm}$ are applied to leach salts below the effective rooting depth. High leaching rates as often implemented in the region are an issue, particularly in the absence of adequate drainage, as this will effectively result in the development of elevated water tables. Moreover, there is a high cost associated with this strategy in terms of limited water resources. In a water-stressed or closed basin area, as is the case in the region, enhancing the productivity of water is essential in order to meet future demands. According to the most 
optimistic scenario, the annual demand for water in the basin will increase to $130 \mathrm{~km}^{3}$ by 2010 , reaching a level of available surface and ground water resources of the region (Dukhovniy et al., 2002). Increasing water use efficiencies at the farm level will also be critical in avoiding a water crisis in the region. Reducing the need for leaching as well as productively using subsurface water resources as demonstrated in this study would result in a reduction in on-farm water requirements and contribute to enhancing environmental flows. In this geopolitically volatile region where water is a key element, enhancing water use efficiencies will also be critical in maintaining regional stability.

The results of this study have clearly demonstrate the efficacy of liquorice in rehabilitating abandoned saline fields over a four year period and bringing them back to a state where the production of wheat and cotton can be undertaken. It has been shown to be a low cost option that can be implemented by resource poor farmers with the potential of increasing incomes and diversifying farming enterprises. The challenge is promoting adoption by farmers through an effective extension programme along with the development of innovative cropping systems and appropriate market infrastructure for liquorice, and the liberalisation of state policies on cropping patterns. Without these changes adoption of bioremediation as a means of reclaiming abandoned saline soils will be slow and sporadic.

\section{Acknowledgements}

The authors are indebted to the Asian Development Bank through RETA 9, who provided partial funding support, and also to Quliev, T.H; candidate of agricultural sciences, Halquziev P.H; candidate of biological sciences and Haydarov N, candidate of agricultural sciences, all from Gulistan State University for carrying out the field experiments and laboratory analysis.

\section{Correspondence}

Any correspondence should be directed to Andrew Noble, International Water Management Institute, Southeast Asia Regional Office, WorldFish Centre, PO Box 500, GPO 10670, Penang, Malaysia (a.noble@cgiar.org).

\section{References}

Abdullaev, I. (2004) How to Live with Salinity in Central Asia: Review of the Situation and Strategy for Remediation. Paper presented at the meeting on Research Program Development for Land Degradation, Drainage and Waste-Water Reuse in Central Asia. 11-17 May, 2004, Tashkent, Uzbekistan.

Akjigitova, N.I. (1981) Halophyte Vegetation of Central Asia and its Indicative Behavior. Tashkent: Fan.

Badalov, M.A. (1996) Multiplication of Liquorice Naked and its Cultivation. Tashkent: Fan.

Cai, X., McKinney, D.C. and Lasdon, L.S. (2003) Integrated hydrologic-agronomic-economic model for river basin management. Journal of Water Resources Planning and Management 129, 4-17.

Cotton Growing Scientific Research Institute (1973) (Souyznikhi) Organization of Field Experiments. Handbook for Researchers. Moscow: Agroizdat.

Dagar, J.C., Tomar, O.S., Kumar, Y. and Yadav, R.K. (2004) Growing three aromatic grasses in different alkali soils in semi-arid regions of northern India. Land Degradation and Development 15, 143-151.

Dukhovniy, V.A. and Sokolov, V.I. (2002) The Integrated Water Resources Management for Aral Sea Basin. Paper of SIC ICWC, Vol. 3.

Helalia, A.M., El-Amir, S., Abou-Zeid, S.T. and Zaghloul, K.F. (1992) Bio-reclamation of salinesodic soil by Amshot grass in northern Egypt. Soil and Tillage Research 22, 109-115.

Hinsinger, P. (1998) How do plant roots acquire mineral nutrients? Chemical processes involved in the rhizosphere. Advances in Agronomy 64, 225-265.

Hyder, S.Z. (1981) Preliminary observations on the performance of some exotic species of Atriplex in Saudi Arabia. Journal of Range Management 34, 208-210.

Kay, B.D. and Angers, D.A. (2000) Soil structure. In M.E. Sumner (ed.) Handbook of Soil Science. Boca Raton, USA: CRC Press.

Kerbabaev, B.B. (1971) Protection of liquorice naked production resources. In Materials of Conference on Protection of Flora of Central Asian Republics and Kazakhstan, (pp. 252-256). Uzbekistan, Tashkent: Fan.

Koval, V.S. and Koval, S.F. (1996) Genetic analysis of salt tolerance of barley. Determination of number of genes. Genetics 32 (8), 1098-1103.

Kumar, A. and Abrol, I.P. (1984) Studies on the reclaiming effort of Karnalgrass and para-grass grown on highly sodic soil. Indian Journal of Agricultural Sciences 54, 189-193.

Lynch, J.M. and Bragg, E. (1985) Microorganisms and soil aggregate stability. Advances in Soil Science 2, 133-171.

MAWR (Ministry of Agriculture and Water Resources Management of Uzbekistan) (2002) Yearly Report of Operations. Unpublished report.

Mikhailova, V.P. (1966) Resources, distribution and experience on growing of liquorice in Kazakhstan. 
In Studies on Experimenting and Using Liquorice in USSR. Moscow: Nauka.

Micklin, P.P. (1991) The Water Management Crisis in Soviet Central Asia. Pittsburgh, PA: University of Pittsburgh. Centre for Russian and East European Studies. (The Carl Beck papers in Russian and East European studies no. 905).

Mudd, J.B. and Kozlowski, T.T. (1975) Response of Plants to Air Pollution. New York: Academic Press.

Muhammed, S., Ghafoor, A., Hussain, T. and Rauf, A. (1990) Comparison of biological, physical and chemical methods of reclaiming salt-affected soils with brackish groundwater. In Proceedings of the 2nd National Congress of Soil Science, 20-22 December 1988, Soil Science Society of Pakistan, Faisalabad, Pakistan, pp. 35-42.

Qadir, M., Qureshi, R.H. and Ahmad, N. (2002) Amelioration of calcareous saline-sodic soils through phytoremediation and chemical strategies. Soil Use and Management 18, 381-385.

Qadir, M., Noble, A.D., Oster, J.D., Schubert, S. and Ghafoor, A. (2005) Driving forces for sodium removal during phytoremediation of calcareous sodic soils. Soil Use and Management 21, 173-180.

Pauzner, L.E. (1971) Methods of protection of natural bushes and experience on introduction of liquorice in Uzbekistan. Materials of Conference on Protection of Flora of Central Asian Republics and Kazakhstan. Uzbekistan: Fan.

Pankova, E.I., Kouzmina, J.W. and Treshkin, S.Y. (2004) The influence of flooding area on soil-vegetation cover of the South Gobi oasis. Water Resources, $21,3$.

Pankova, E.I., Kouzmina, J.W. and Treshkin, S.Y. The state of tugai vegetation in south Mongolian oasis and perspective their restoration. Arid Ecosystems 2, 2-3.

Rahimabaev, F.M. and Gasanova, G.K. (1986) Calculation of the Ameliorative Parameters of Irrigation Systems. Tashkent: Mehnat.

Rozanov, A.N. (1989) Serozemi Sredney Azii (Serozems of Central Asia) (pp. 67-72). Moscow: Academy of Science.

Tokhtarov, V.P. (2004) Sorghum: Predecessor, fertilizing, soil treatment. Sorghum and Corn 5, P1768, 22-24.

WEMP (2003) Water and Environmental Management Project Sub-component A1, National and Regional Water and Salt Management Plans. Draft Regional Policy, Strategy, and Action Program for Water and Salt Management. Regional Report 3. Royal Haskoning, The Netherlands.

World Bank (2003) Assessment of Irrigation and Drainage Infrastructure in Uzbekistan (Russian). Report. 